\title{
Bedre antikoagulasjonsbehandling?
}

Etter å ha vært enerådende i 50 år har warfarin fått konkurranse av nye perorale antikoagulasjonsmidler (1). Spørsmålet er: Hvilken plass skal disse midlene og warfarin ha i fremtiden? For noen pasienter er svaret klart: Alle med kunstige hjerteklaffer skal behandles med warfarin. For flertallet er valget åpent. I dette nummer av Tidsskriftet presenteres de nye perorale antikoagulasjonsmidlene i en oversiktsartikkel - med omtale av kliniske studier og praktiske råd (2).

Tre midler er godkjent i Europa: dabigatran, rivaroksaban og apiksaban. De dekker de viktigste indikasjonene: tromboseprofylakse ved ortopedisk kirurgi, embolismeforebygging ved atrieflimmer samt behandling og forebygging av venetrombose og lungeembolisme.

I 2012 var det ifølge Reseptregisteret 94526 personer som hentet warfarin på apoteket. De nye perorale antikoagulasjonsmidlene hadde til sammenlikning bare 5752 brukere, hvilket skyldes at refusjon ved atrieflimmer først kom på plass 1.1. 2013. I 2013 vil antallet brukere øke sterkt, vårt anslag er 18000 pasienter ved utgangen av året. Legemiddelverkets beregninger viser at dabigatran, til tross for høyere legemiddelpris, er et kostnadseffektivt alternativ til warfarin (3). Dette skyldes særlig innsparinger på INR-prøver. I 2009 ble det utført 1,8 millioner INR-prøver (3). Om 10-15 år går patentene på de nye perorale antikoagulasjonsmidlene ut, og prisen vil da antakelig blir sterkt redusert. Den økonomiske fordelen for disse midlene blir da stor, ettersom totalkostnadene for warfarinbehandling vil være uendret. Kunnskapssenteret har konkludert med at de nye perorale antikoagulasjonsmidlene hver for seg synes å være kostnadseffektive sammenliknet med warfarin, selv om anslagene er usikre (4).

Men så tilbake til spørsmålet: Hvilken plass skal de nye perorale antikoagulasjonsmidlene ha? Diskusjonen har dreid seg om hvorvidt disse midlene er «bedre» enn optimal warfarinbehandling eller ikke. I studiene der man har sammenliknet de nye midlene med warfarin ved atrieflimmer, har de en slagforebyggende virkning som er like god eller bedre enn warfarinets $(5-7)$. Mye av effekten skyldes færre hjerneblødninger. Tidsskriftets lesere er blitt oppfordret til å ha kaldt vann i blodet på grunn av usikkerhet ved studiene og spørsmål om etterlevelse i praksis (8).

Personlig har jeg det enkle og pragmatiske syn at alle antikoagulasjonsmidler er omtrent like effektive, men at de nye midlene har en fordel når det gjelder enkel behandling. Uansett må antikoagulasjonsbehandling utnyttes optimalt - riktig legemiddel med riktig dose til riktig pasient. For legen betyr de nye midlene omlegging av rutinene. I stedet for å stole på INR-prøver må man tilpasse dosen etter indikasjon, alder, nyrefunksjon og interaksjoner. De nye midlene gir flere valgmuligheter, legens oppgave er å veilede pasienten slik at de i fellesskap kommer frem til riktig valg. Man må ikke glemme at opplæring av pasientene er viktig: De må ta medisinene nøyaktig som bestemt og følge rådene i pakningsvedlegget. Jeg anbefaler alle pasientene mine å legge inn en alarm på mobiltelefonen, slik at de husker å ta medisinen. Mye skal læres, det kan være klokt å ile langsomt. Start med pasienter som begynner med nye perorale antikoagulasjonsmidler, deretter kan man vurdere bytte hos dem som allerede bruker warfarin.
Like viktig som å ha håndlaget med forskrivningen er det å følge retningslinjene for hvem som skal ha antikoagulasjonsbehandling, hvem som kan bruke nye perorale antikoagulasjonsmidler og hvem som skal ha warfarin. De nye europeiske retningslinjene setter de nye antikoagulasjonsmidlene ørlite foran warfarin ved atrieflimmer (9).

Artikler om virkningen av de nye perorale antikoagulasjonsmidlene i vanlig praksis begynner å komme. To danske studier viser at dabigatran har omtrent samme effekt som warfarin $(10,11)$. I den ene var resultatene for dabigatran bedre hos dem som begynte med behandling enn hos dem som skiftet fra warfarin til dabigatran.

Leger som skriver ut antikoagulasjonsmidler, enten det er de nye eller warfarin, må følge preparatomtalene og aktuelle retningslinjer. Artikkelen til Ghanima og medarbeidere (2) og informasjon fra Helsedirektoratet (12) og Legemiddelverket er verdifulle i så måte. Tiden vil vise hvilken plass de forskjellige midlene vil få. La oss håpe at vi går inn $\mathrm{i}$ en æra med riktig antikoagulasjonsbehandling av hensyn til pasientene.

\section{Steinar Madsen}

steinar.madsen@legemiddelverket.no

Steinar Madsen (f. 1956) er medisinsk fagdirektør ved Statens legemiddelverk og har deltidsstilling som avtalespesialist $\mathrm{i}$ indremedisin og hjertesykdommer

Forfatter har fylt ut ICMJE-skjemaet og oppgir ingen interessekonflikter.

\section{Litteratur}

1. Reikvam A.. Er warfarinæraen over? Tidsskr Nor Legeforen 2012; 132: 2583.

2. Ghanima W, Atar D, Sandset PM. Nye perorale antikoagulasjonsmidleren oversikt. Tidsskr Nor Legeforen 2013; 133: 1940-5.

3. Statens legemiddelverk. Refusjonsvurdering for Pradaxa (dabigatran) oversendt Helse- og omsorgsdepartementet. www.legemiddelverket.no/Nyheter/ Blaa_resept_og_pris/Sider/Refusjonsvurdering-for-Pradaxa-(dabigatran)oversendt-Helse--og-omsorgsdepartementet.aspx (26.8.2013).

4. Wisløff T, Ringerike T, Hagen $G$ et al. Rapport fra Kunnskapssenteret nr. 05-2013. www.kunnskapssenteret.no/Publikasjoner/Efficacy+and+costeffectiveness+of+new+oral+anticoagulants+compared+to++warfarin+for+the+ prevention+of+stroke+in+patients+with+atrial+fibrillation.17830.cms (26.8.2013).

5. Connolly SJ, Ezekowitz MD, Yusuf S et al. Dabigatran versus warfarin in patients with atrial fibrillation. N Engl J Med 2009; 361: 1139-51.

6. Patel MR, Mahaffey KW, Garg J et al. Rivaroxaban versus warfarin in nonvalvular atrial fibrillation. N Engl J Med 2011; 365: 883-91.

7. Granger CB, Alexander JH, McMurray JJ et al. Apixaban versus warfarin in patients with atrial fibrillation. N Engl J Med 2011; 365: 981-92.

8. Dyrkorn R, Roland PDH. Nye antikoagulantia - bør vi ha litt kaldt vann i blodet? Tidsskr Nor Legeforen 2013; 133: 390-1.

9. Camm AJ, Lip GY, De Caterina R et al. 2012 focused update of the ESC Guidelines for the management of atrial fibrillation: an update of the 2010 ESC Guidelines for the management of atrial fibrillation. Developed with the special contribution of the European Heart Rhythm Association. Eur Heart J 2012; 33: $2719-47$.

10. Larsen TB, Rasmussen LH, Skjøth F et al. Efficacy and safety of dabigatran etexilate and warfarin in «real-world» patients with atrial fibrillation: a prospective nationwide cohort study. J Am Coll Cardiol 2013; 61: 2264-73.

11. Sørensen R, Gislason G, Torp-Pedersen C et al. Dabigatran use in Danish atrial fibrillation patients in 2011: a nationwide study. BMJ Open 2013. E-publisert 3.5.

12. Helsedirektoratet. Informasjon om de nye perorale antikoagulasjonsmidlene dabigatran, rivaroksaban og apiksaban. www.helsedirektoratet.no/ publikasjoner/informasjon-om-de-nye-perorale-antikoagulasjonsmidlenedabigatran-rivaroksaban-og-apiksaban/Sider/default.aspx (26.8.2013) 